DOI: http://doi.org/10.31617/k.knute.2019-04-12.76

PrymaViktoriia

PhD (Germanic Languages)

Kyiv National University of Trade and Economics

Kyiv, Ukraine

https://scholar.google.ru/citations?hl=ru\&pli=1\&user=jgOQKt8AAAAJ

https://orcid.org/0000-0001-7331-9950

ResearcherID: N-1582-2016

\title{
GLOBALIZATION OF TOURISM DISCOURSE
}

In the age of globalization cultural-cognitive tourism becomes of particular importance, as it gives the opportunity to return to the study of the cultural heritage of humanity, its humanistic content. Today, cultural-cognitive tourism develops in three interrelated areas: knowledge of culture and cultural heritage, protection and revival of culture and dialogue of cultures. The interest in the tourist discourse of cultural and cognitive activity is explained by the rapid development and spread of the tourism industry and its influence on various aspects of the life of modern man.

Researchers pay close attention to the study of tourism (I. Zorin, V. Kvartalnov, O. Sesolkin) and N. Harutyunov, S. Balli, M. Bakhtin, A. Wezhbitskaya) separately, but the ways of their intersection and interaction have received much less attention. Therefore, it is relevant to study the topic that is not sufficiently studied and to pay attention to the peculiarities of the functioning of tourist discourse in cultural-cognitive tourism and the expression of communicative tactics by modern means of English.

The study of tourist discourse goes beyond specific disciplines. Tourist discourse should be classified as a public discourse of a global nature, since it brings together millions of people who are actively involved in its formation as part of a host of communicative situations. Objects of tourist discourse can be considered culture, history, traditions.

There are several approaches to defining the notion of «tourism». $\mathrm{N}$. Reymerson points out that tourism is any trip for recreation and acquaintance with new regions and objects, and O. Beidyk treats tourism as a form of mass travel and rest in order to get acquainted with the 
environment, which is characterized by environmental, educational and other functions [1].

Tourism, first of all, satisfies the needs of people in recreation, hedonistic and aesthetic needs, as well as human needs in obtaining new information. It should be emphasized that the forms of tourism are constantly being improved [3]. Today there are many different types of tourism, namely: business; educational; shopping tourism; extreme; sports; pilgrimage; historical; cultural and cognitive, etc.

As for tourist discourse, one of the most important tasks is to determine its typological status. There are two approaches to studying this problem. According to the first approach, tourist discourse is a subset of institutional advertising discourse [8]. Another approach defines tourism discourse as an independent form of discourse, which has the ability to interact with other types of discourse, in particular scientific, advertising, etc. $[7 ; 32]$.

Most thoroughly the issue of tourist discourse was studied by C. Terlow and A.Javorski (C. Thurlow, A. Jaworski). Their work presents a detailed analysis of the role of oral, written and visual discourse in the development of tourism as a global cultural industry [9].

The research of tourist discourse has an interdisciplinary character and is conducted in various directions, in particular, sociolinguistic, cultural, ethnographic and others. The discourse of cultural-cognitive tourism is realized on the background of other types of discourse.

\section{LIST OF USED SOURCES}

1. Beydyk O. Dictionary of reference on the geography of tourism, recreation and recreational geography / O. O. Beydyk. - K .: Palette, 1997.

2. Goncharova L.M. Communicative Possibilities of Speech tactics in promotional texts / L. M. Goncharova. - Vestnik MGOU, - No. 2, 2010. - P. 21-25.

3. I. I. Ilyina, Fundamentals of Tourism Activity / E.I. Ilyin. - Moscow: 2000. -297 pp.

4. Isers O.S. Speech Impact: A Study Guide / O. S. Isser. - M .: Flint Nauka, 2008. - 226 p. 
5. Isers O.S. Communicative Strategies and Tactics of Russian Speech / O. S. Isser. - Moscow: Editorial URSS, 2002. - 284 p.

6. Loiko O.T. Tourism and Hospitality.Tutorial / O.T. Loiko. - Tomsk: TPU Publishing House, 2005. - 152 p.

7. Mikhailov N. N. The English language for the directions «Service» and «Tourism»/ N. N. Mikhailov. - Moscow: Academy, 2011. - 198 p.

8. Filatova NV Genre space of tourist discourse // Philological sciences / NV Filatova. - Moscow: - 2012. - No. 2. - P. 76-82.

9. Thurlow C. Tourism discourse: language and global mobility / C. Thurlow, A. Jaworski. - Basingstoke : Palgrave Macmilan, 2010. $288 \mathrm{p}$. 